\title{
The Ameriorating Effects of Grapefruit Seed Extract on Testicular Morphology and Function of Varicocelized Rats
}

\author{
Efecto de Aminoramiento del Extracto de Semilla de Pomelo \\ en la Morfología y Función Testicular de Ratas Varicocelizadas \\ "Saalu, L. C.; "*tUdeh, R.; "* Oluyemi, K. A.; "Jewo, P. I. \& ***Fadeyibi, L. O.
}

SAALU L. C.; UDEH, R.; OLUYEMI, K. A.; JEWO, P. I.; \& FADEYIBI, L. O. The ameriorating effects of grapefruit seed extract on testicular morphology and function of varicocelized rats. Int. J. Morphol.,26(4):1059-1064, 2008.

SUMMARY: Varicoceles are abnormal tortuosity and dilatation of the veins of the pampiniform plexus that drain the testis. The pathophysiology of testicular damage in varicocele has not been completely understood. However there is an increasing body of evidence pointing towards the role of reactive oxygen species and oxidative stress in the pathogenesis of varicocele related subfertility. In the present study we examined the role of proanthocynidin-rich ethanol extract of grapefruit seed as an antioxidant in protecting the testis against damage in experimental varicocele. Three groups of rats were constructed as the first group had intact rats; experimental bilateral varicoceles were established by complete ligation of the left and right main spermatic veins in the later two groups. The third group had in addition daily gavage administration of $10 \mathrm{mg} / \mathrm{kg}$ body weight ethanol extract of grapefruit seed. Eight weeks after varicocele induction, bilateral testicular weights, bilateral testicular volumes, bilateral caudal epididymal sperm characteristics, and bilateral testicular histology and serum hormone levels were tested. It was found that the testes of grapefruit seed extract treated animals had better functional and histological profiles compared to the untreated varicocelized animals. These results indicated the effectiveness of grapefruit seed extract for preservation of testes function morphology in varicocelized subjects.

KEY WORDS: Varicocele; Grapefruit seed extract; Testis; Infertility.

\section{INTRODUCTION}

Varicoceles are variously considered the commonest "correctable" cause of infertility or the commonest "reported" cause of infertility, depending on individual viewpoint. This dichotomy has resulted from a lack of clear understanding of the effects of varicoceles on spermatogenesis. Thus the pathogenesis of testicular damage or the mechanism of which varicocele produces sperm dysfunction has not been clearly identified yet (Santoro et al., 2001). The proposed mechanisms include testicular hypoxia by venous stasis and small vessel occlusion, leading to Leydig cell and germinal cell dysfunction, increased testicular and scrotal temperature and decrease in gonadotrophin and androgen secreation (Hudson, 1988).

Reactive Oxygen Species (ROS) were shown to be constantly produced by spermatozoa and spermatozoal membrane, which is rich in polyunsaturated fatty acids, is susceptible to peroxidation in the presence of elevated seminal ROS levels (Hendin et al., 1999). ROS are cytotoxic and cause tissue injury in several pathophysiologies, such as cancer, glomerular nephritis and arthritis. Thus sperm dysfunction may be a consequence of elevated seminal ROS. Several studies have also demonstrated that in the presence of increased antioxidant enzyme levels, testicular dysfunction can be prevented in varicocelized subjects (Hendin et al.; Suziki \& Sofikitis, 1999; Sharma \& Agarwal, 1996).

Treatments involving antioxidants have been used successfully to decrease oxidative stresss related injuries in many organ systems as well as in testis (Suziki \& Sofikitis; Ozokutan et al., 2000; Saalu et al., 2006). Grapefruit Seed Extract (GSE) from grapefruit (Citrus paradise) contains high levels of Vitamin C, Vitamin E and bioflanoids (naringenin). These compounds are powerful antioxidants individually and collectively. GSE is therefore now regarded as the most powerful natural antioxidant available (Sachs, 1997).

\footnotetext{
* Department of Anatomy, Lagos State University College of Medicine (LASUCOM), Ikeja Lagos.

** Department of Anatomy, College of Health Sciences, Igbinedion University, Okada.

*** Department of Surgery, Lagos State University College of Medicine (LASUCOM), Ikeja Lagos.
} 
Although varicocelectomy is considered as a highly effective treatment of infertility due to varicoceles, a significant number of men remain infertile after varicocelectomy (Sofikitis \& Miyagawa, 1992). Therefore there is an increasing interest to develop conservative modes of therapy of infertility due to varicoceles. Considering that Oxygen radical scavengers provide significant restoration of testicular function after testicular vascular diseases (Henry et al., 1996; Saalu et al., 2007), we aim to study the effect of the administration of GSE on testicular morphology,and testicular spermatogenic and steroidogenic functions in rats with experimental varicoceles.

\section{MATERIAL AND METHOD}

Plant Materials. The ripe grapefruits were obtained at Bariga Market Lagos. The plant material was identified and authenticated at the Forestry Research Institute of Nigeria where a voucher specimen with herbarium number F.H.I 106998 has deposited. The air dried seeds were reduced to a powdered substance by grinding. The sample was exhaustively extracted with ethanol by means of a soxlet apparatus and the extract was evaporated in vacuo. The residue was processed to give $10 \mathrm{~g}$ ( $7.5 \%$ yields) of dark yellowish solid crude mass, which was stored at $4 \mathrm{o} \mathrm{C}$ for the study. Fresh solution of the extract was prepared in peanut oil when required.

Animals. Adult male Sprague - Dawley rats weighing 240 $-290 \mathrm{~g}$ were used for the study. The animals were kept in the Animal House of Department of Anatomy, LASUCOM, Ikeja and housed in wire mesh cages under standard environmental conditions with the provision of $12 \mathrm{~h}$ light and 12h darkness. Rats (Pfizer feeds Nigeria Limited, Lagos, Nigeria) and water were provided ad libitum.

Experimental protocol. Thirty six male rats were weighed and divided randomly into three groups of twelve rats each. Group A served as the control and the rats were neither rendered varicocelized nor treated with GSE. Groups B and $\mathrm{C}$ served as experimental groups in which the rats were rendered bilaterally varicocelized. To induce varicocele, the animals were anaesthetized with intra-abdominal injection of $7 \mathrm{mg} / \mathrm{kg}$ body weight ketemine hydrochloride. A $2 \mathrm{~cm}$ median incision was made through the skin, beginning caudal to the prepuce and extending cranially. The right and left spermatic vein were exposed and ligated completely with a 4-0 nylon suture as described by Sofikitis \& Miyagawa. Group $C$ in addition had gavage administration of $10 \mathrm{mg} / \mathrm{kg}$ body weight ethanol extract of GSE daily for eight weeks.
Autopsy, organ weight and volume estimation. At the end of the experimental period, each rat was weighed and sacrificed by decapitation. The testis were excised, dissected free of surrounding tissue, their weights determined and volumes measured by water displacement method.

Sperm Characteristics. The testes from each rat were carefully exposed and removed. They were trimmed free of the epididymides and adjoining tissues. From each separated epididymis, the caudal part was removed and placed in a beaker containing $1 \mathrm{~mL}$ physiological saline solution. Each section was quickly macerated with a pair of sharp scissors and left for a few minutes to liberate its spermatozoa into the saline solution. Sperm motility, concentration and progressive motility were determined as earlier described (Saalu et al., 2006, 2007). Semen drops were placed on the slide and two drops of warm $2.9 \%$ sodium citrate were added. The slide was covered with a cover slip and examined under the microscope using X40 objective for sperm motility. Sperm count was done under the microscope using improved Neubauer haemocytometer.

Estimation of plasma levels of testosterone. Plasma testosterone concentrations were estimated using the Enzyme Immunology Assay (EIA) method as earlier described (Saalu et al., 2006). Plasma samples were collected were stored at $-20^{\circ} \mathrm{C}$ while assayed. The EIA kits used were obtained from Immunometrics (London U. K) and contained testosterone EIA substrate reagents and EIA quality control samples. A quality control sample was run for the hormone at the beginning and at the end of the assay variation. The EIA kit used had a sensitivity level of $0.3 \mathrm{nmol} / \mathrm{L}(0.1 \mathrm{ng} / \mathrm{mL})$. The intra and inter assay variations were 11.00 and $10.10 \%$ respectively.

Histological Analysis. This was done as essentially as described by Akpantah et al., (2003). The organs were cut in slabs of about $0.5 \mathrm{~cm}$ thick and fixed in Bouin's fluid for a day after which it was transferred to $70 \%$ alcohol for dehydration. The tissues were passed through $90 \%$ alcohol and chloroform for different durations before they were transferred into two changes of molten paraffin wax for 20 min each in an oven at $57^{\circ} \mathrm{C}$. Serial sections of $5 \mu \mathrm{m}$ thick were obtained from a solid block of tissue and were stained with haematoxylin and eosin stains, after which they were passed through a mixture of equal concentration of xylene and alcohol. Following clearance in xylene, the tissues were oven-dried. Light microscopy was used for the evaluations.

Statistical Analysis. Data were expressed as mean \pm SEM. They were subjected to analysis of variance (ANOVA). Statistical significance between the various groups was separated by $\mathrm{t}$ - test (SAS, 2002). 


\section{RESULTS}

Body Weight Changes. Table I shows that rats in control group had significant $(\mathrm{P}<0.05)$ increase in weight. Both varicocelized groups lost weights when compared with their initial weights. However the weight loss by the varicocelized rats that received GSE was higher than the losses by varicocelized group that did not receive GSE.

Weights and Volume of testes mean. Table I also shows that the testicular weights and volumes of the varicocelized alone were the least, being significantly lower $(\mathrm{P}<0.05)$ compared to the mean testicular weights and volumes of the varicocelized rats that in addition had GSE.

Epididymal Sperm Characteristics. Spermatozoa concentration: As shown in Table II, the varicocelized alone group had marked oligospermia with their sperm concentration being significantly lower $(\mathrm{P}<0.01)$ compared to the control group. The varicocelized with GSE group however showed only moderate oligospermia, the sperm concentration being significantly lower $(\mathrm{P}<0.05)$ than the control group.

Spermatozoa motility: Even though percentage sperm motility of both the varicocelized alone and varicocelized with GSE groups were significantly lower $(\mathrm{P}<0.01$ and
$\mathrm{P}<0.05$ respectively) compared to the control group, the varicocelized with GSE group still had a significantly higher $(\mathrm{P}<0.05)$ sperm motility than the varicocelized alone group (Table II).

Progressivity of spermatozoa motility: The sperm cells from the cauda epididymides of both varicocelized alone and varicocelized with GSE groups showed sluggish linear or non-linear movement. Spermatozoa from the control group exhibited progressive rapid linear movement.

Serum Testosterone Levels. There was no significant $(\mathrm{P}<0.05)$ difference in the peripheral serum basal testosterone levels between the control rats and the other two groups. The testosterone levels in the experimental groups did not also significantly $(\mathrm{P}<0.05)$ differ from one another (Table III).

Testis Morphology. Light microscopy was used for evaluation of testicular histology as shown in Figs. 1-3. The seminiferous tubules of the control rats were completely differentiated. Spermatozoa are shown in some of the tubules. However in the two experimental groups. The testis showed atrophy of the seminiferous tubules, degeneration of the germinal epithelium and absence of late stage germ cells.

Table I. Body Weights (g), Testicular Weights (g) and Testicular Volumes (mL).

\begin{tabular}{lccc}
\hline Parameter & Varicocelized without GSE & Varicocelized with GSE & Control \\
\hline Initial live body weight & $270.36 \pm 13.20$ & $250.14 \pm 12.60$ & $260.43 \pm 15.00$ \\
Final live body weight & $265.55 \pm 35.60$ & $235.23 \pm 14.50$ & $295.74 \pm 26.00$ \\
Body weight difference & $4.81[1.78]$ & $14.91[5.96]$ & $35.31[35.35]$ \\
Testicular weight & $0.62 \pm 0.14^{*}$ & $1.68 \pm 0.07$ & $1.94 \pm 0.62$ \\
Testicular volume & $0.67+0.16^{*}$ & $1.69 \pm 0.08$ & $1.97+0.40$
\end{tabular}

*P<0.05 compared to control group, [ ] Percentage.

Table II. Sperm Characteristics.

\begin{tabular}{lccc}
\hline Parameter & Varicocelized Alone & Varicocelized with GSE & Control \\
\hline Sperm concentration $\left(\mathrm{X} 10^{6} / \mathrm{mL}\right)$ & $1.55 \pm 5.70^{* *}$ & $25.5 \pm 6.08 *$ & $59.0 \pm 8.00$ \\
Sperm motility $(\%)$ & $8.0 \pm 3.03 * *$ & $21.0 \pm 6.54 *$ & $72.9 \pm 5.22$ \\
Progressivity & $\mathrm{b}_{1}$ & $\mathrm{~b}_{1}$ & $\mathrm{a}_{1}$ \\
\hline$*$ P $<0.05$ compared with the control group. ${ }^{*} \mathrm{P}<0.01$ compared with the control group. a1 = Rapid linear progressive motility, $\mathrm{b} 1=$ \\
Sluggish linear or non - linear motility
\end{tabular}

Table III: Serum Testosterone Levels (ng/ mL).

\begin{tabular}{lc}
\hline Groups & Testosterone level \\
\hline Control & $2.92 \pm 0.30$ \\
Varicocelized alone & $2.87 \pm 0.60$ \\
Varicocelized with GSE & $2.93 \pm 0.60$ \\
\hline
\end{tabular}

These degenerative changes were shown to be more marked in the rats that were made varicocelized without receiving GSE than in those that received after being made varicocelized. 


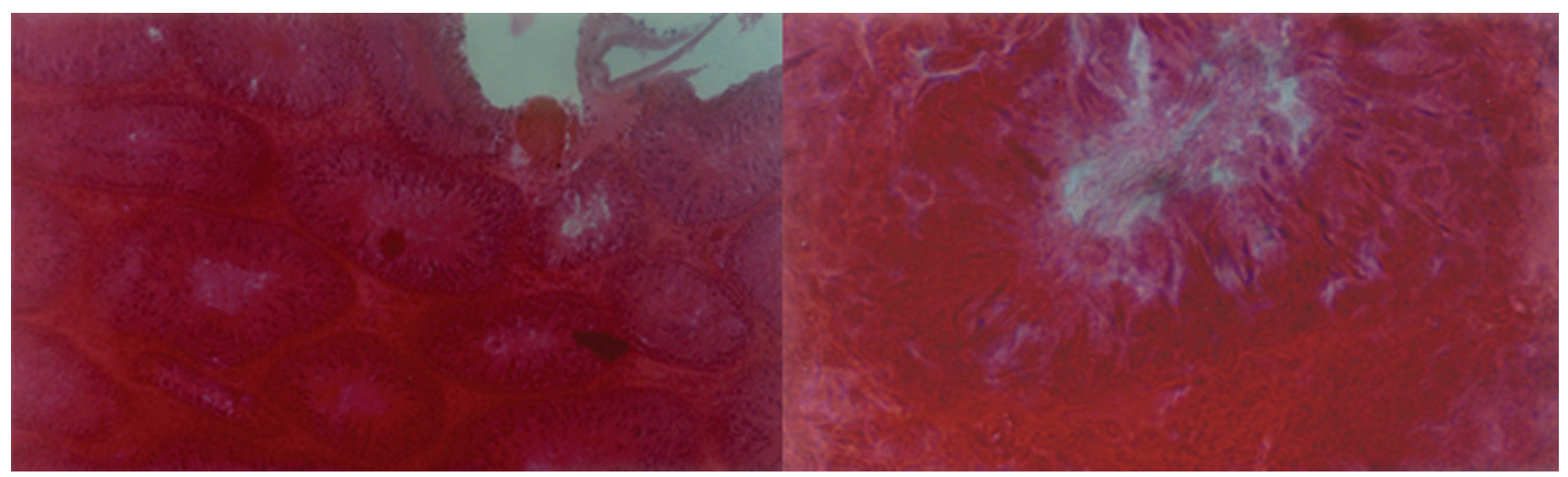

Fig. 1. Section through testis of control rats. Completely differentiated seminiferous tubules, spermatozoa shown in some of the tubules. Left H \& E (X160), Rigth H \& E (X 800).

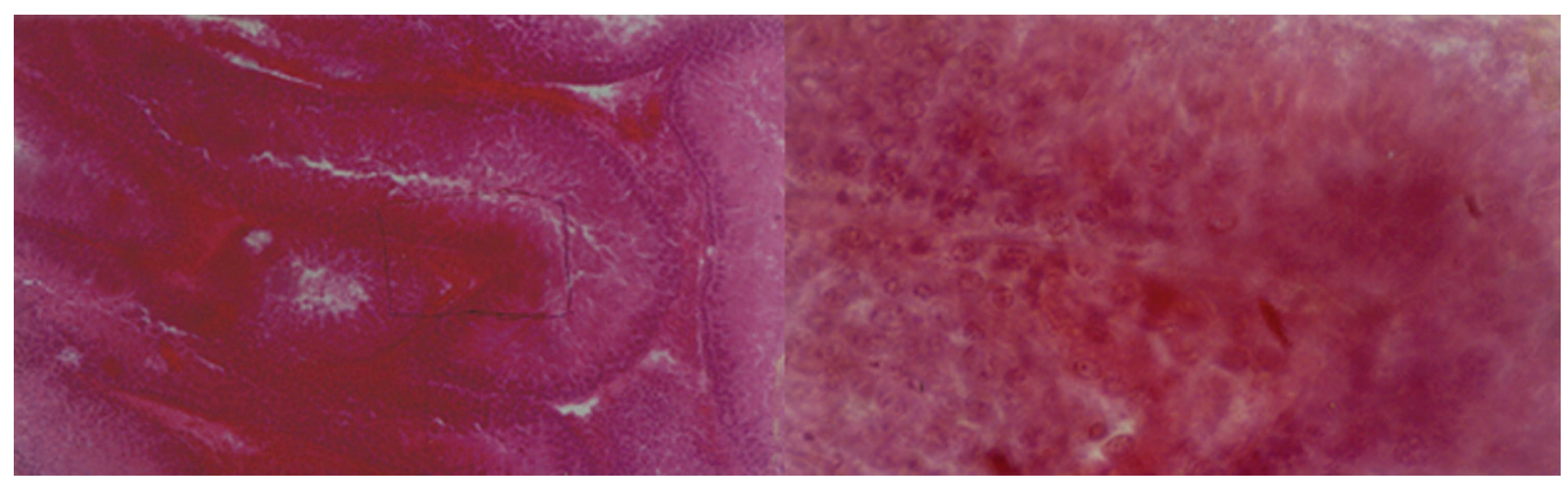

Fig. 2. Section through testis of varicocelized rats without GSE treatment. Marked degeneration of the germinal epithelium and absence of late stage germ cells. Left H \& E (X160), Rigth H \& E (X 800).

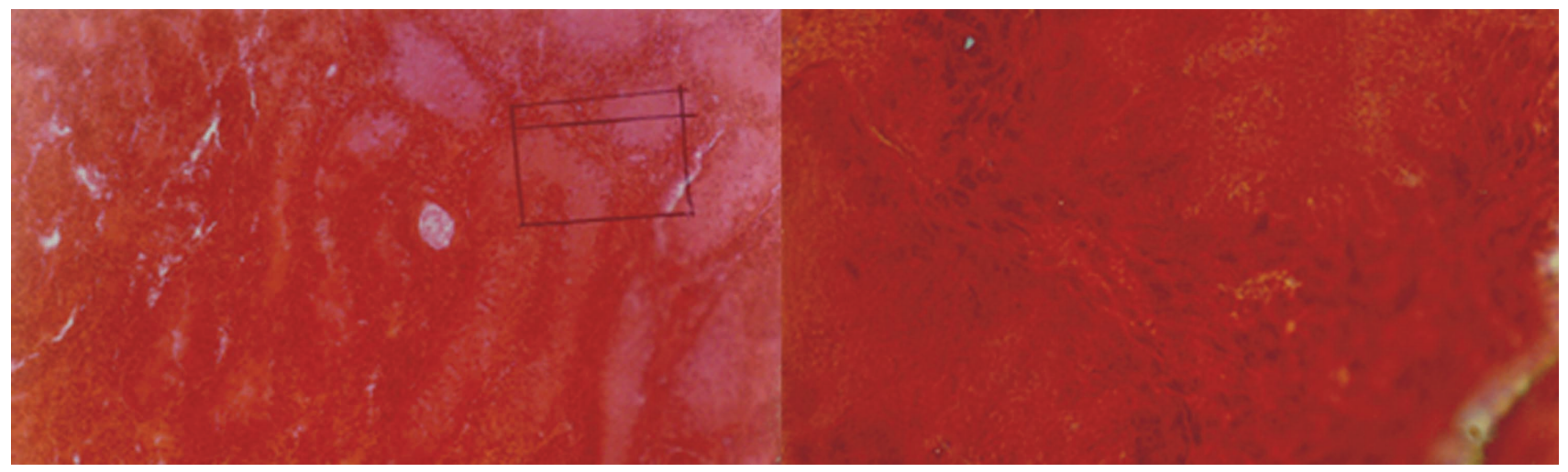

Fig. 3. Section through testis of varicocelized rats with GSE treatment. Moderate seminiferous tubules atrophy and presence of some late stage germ cells in some tubules. Left H \& E (X160), Rigth H \& E (X 800).

\section{DISCUSSION}

The findings from our present study demonstrated that experimental varicocele inhibited growth and reproductive capacity of male Sprague Dawley rats. The gain in live body weight of the control rats could mean that the rats were still in the active growth phase. The loss in live body weight of the experimental groups indicates that artificial varicocele has a negative effect on the body metabolic process (Özdamar et al., 2004). 
The procedure for achieving artificial varicocele confers a conspicuous level of stress on the rats. This stress could affect their metabolic process leading to losses in live weights observed in this study.

The lower testes weights in varicocele compared to the control corroborate the report of Suziki \& Sofikitis. Semercioz et al. (2003), also reported degenerative changes in the semniferous epithelium of testes that were made varicocelized, due to the effects of heat from venous stasis on the spermatogenic cells within the epithelium leading to loss in testicular weight.

That the mean testicular weight of varicocelized with GSE, which had a lower mean final live weight was significantly $(\mathrm{P}<0.05)$ higher than the mean testicular weight of varicocelized alone group is an indication of the moderating effects of GSE treatment. Varicocele, which a leading cause of male infertility is associated with increased production of spermatozoal ROS. Irrespective of the infertility status, it was identified that there is a strong relationship between sperm dysfunction and varicocele (Lewis et al., 1995; Hendin et al.). Indeed Hendin et al., reported a 4-fold increase in the frequency of elevated ROS generation in the incidental varicocele group compared to their control patients.

The results from our present study showed a moderate oligospermia $\left(25.5 \pm 6.08 \times 10^{6} / \mathrm{mL}\right)$ in the varicocelized rats that had GSE. This is a significant improvement over the the marked oligospermia $\left(1.55 \pm 5.70 \times 10^{6} / \mathrm{mL}\right)$ observed in varicocelized rats that were not GSE. This confirms the moderating effect of GSE as potent antioxidant and a free radical scavenger (Sachs). Furthermore, treatment with GSE improved bilateral testicular functions and helped the epididymal sperm maturation process as indicated by the significantly higher cauda epididymal sperm motility. Administration of GSE may support the natural antioxidant mechanism of testicular tissue and partly protects the tissue damage due to indunction of varicocele. However it should be emphasized that despite proven benefits of GSE administration, the values of quatitative and qualitative sperm parameters remain significantly lower than those of the control group.

The attenuating effects of GSE are further demonstrated by the significant improvement in the histological profiles of varicocelized with GSE group when compared to the testicular morphology of the varicocelized alone group. Our study did not reveal any significant difference in the serum basal testosterone concentration between varicocelized and intact animals. This however does not indicate an absence of difference in Leydig cell secretory function between the two groups since delicate alterations in Leydig cell secretory function may not be accompanied by alterations in peripheral serum androgen levels (Saypol et al., 1981).

In conclusion, our study showed a protective effect of GSE on testicular morphology and spermatogenic functions. This has raised the possibility of administering GSE to men with varicocele who have failed to improve sperm quantitative and qualitative parameters after varicocelectomy.

SAALU L. C.; UDEH, R.; OLUYEMI, K. A.; JEWO, P. I.; \& FADEYIBI, L. O. Efecto de aminoramiento del extracto de semilla de pomelo en la morfología y función testicular de ratas varicocelizadas. Int. J. Morphol.,26(4):1059-1064, 2008.

RESUMEN: Los varicoceles son tortuosidades anormales y dilataciones de las venas del plexo pampiniforme que drenan el testículo. La fisiopatología del daño testicular en el varicocele no se ha entendido completamente. Sin embargo, existe un creciente cúmulo de evidencias que apunta hacia el papel de especies reactivas al oxígeno y al estrés oxidativo, en la patogénesis del varicocele relacionados con subfertilidad. En el presente estudio, se examinó el papel de proantocianidina en el extracto etanólico de semilla del pomelo, como un antioxidante en la protección contra el daño testicular experimental en el varicocele. Tres grupos de ratas fueron seleccionados, un grupo de ratas control y dos grupos experimentales. En estos dos últimos grupos, se provocó varicocele bilateral a través de la ligadura completa de las venas testiculares principales izquierda y derecha. El tercer grupo tuvo además una sonda de administración diaria de $10 \mathrm{mg} / \mathrm{kg}$ de peso corporal, de extracto etanólico de semilla de pomelo. Ocho semanas después de la inducción de varicocele, se determinanó el peso testicular bilateral, volúmenes testiculares bilaterales, características de los espermatozoides de la cola del epidídimo bilateral, la histología testicular bilateral y los niveles séricos de hormona. Se determinó que los testículos de los animales tratados con extracto de semilla de pomelo presentaban una mayor funcionalidad y mejores perfiles histológicos, en comparación con los animales varicocelizados no tratados. Estos resultados indican la eficacia de extracto de semilla de pomelo para la conservación de la morfología funcional testicular, en sujetos varicocelizados.

PALABRAS CLAVE: Varicocele; Extracto de semilla de pomelo; Testículo; Infertilidad. 


\section{REFERENCES}

Akpantah, A. O.; Oremosu, A. A.; Ajala, M. O.; Noronha, C. C. \& Okanlawon, A. O. The effect of crude extract of Garcinia kola seed on the histology and hormonal milieu of male Sprague-Dawley rats' reproductive organs. Nig. J. Health and Biomed. Sci., 2(1):40-46, 2003.

Henry, M. P.; Howard, S. S. \& Turner, T. T. Repair of experimental varicoceles in rats. Long-term effects on testicular blood flow and temperature and Caudaepididymal sperm concentration and motility. $J$. Androl., 7:271-6, 1986.

Hendin, B. N.; Kolettis, P. N.; Sharma, R. K. \& Thomas, A. Varicocele is associated with elevated spermatozoal reactive oxygen species production and diminished seminal plasma antioxidant capacity. J. Urol., 161:18314, 1999.

Hudson, R. W. The endocrinology of varicocele. Fertil. Steril., 49:199-208, 1988.

Lewis, S. E.; Boyle, P. M.; McKinney, K. A.; Young, I. S. \& Thompson, W. Total antioxidant capacity of seminal plasma is different in fertile and infertile men. Fertil. Steril., 64:868-70, 1995.

Özdamar, A. S.; Soylu, A. G.; Çulha, M.; Özden, M. \& Gökalp, A. Testicular oxidative stress effects of experimental varicocele in adolescent rats. Urol. Int., 73:3437, 2004.

Ozokutan, B. H.; Kucukaydin, M.; Muhtaroglu, S. \& Tekin, Y. The role of nitricoxide in testicular ischemiareperfusion injury. J. Pediatr. Surg., 35:101-3, 2000.

Saalu, L. C.; Togun, V. A.; Oyewopo, A. O. \& Raji, Y. Artificial crypptorchidism and the moderating effect of melatonin in Sprague-Dawley rats. J. Appl. Sci., 6(14):2889-94, 2006.

Saalu, L. C.; Oluyemi, K. A.; \& Omotuyi, I. O. a-Tocopherol (vitamin E) attenuates the testicular toxicity associated with experimental cryptorchidism in rats. Afr. J. Biotechnol., 6(12):1373-7, 2007.

Sachs, A. The Authoritative guide to grapefruit extract, Stay Healthy Naturally, Life rhythm. California, Medocino, 1997. pp. 775-95.

Santoro, G.; Romeo, C.; Impellizzeri, P.; Cutroneo, G. \&
Trimarchi, F. Nitricoxide synthase patterns in normal and varicocele testis in adolescents. BJU Int., 88:967-73, 2001.

Saypol, D. C.; Howards, S. S.; Turner, T. T. \& Miller, E. D. Influence of Surgically induced Varicocele on testicular Blood flow, temperature and histology in adult rats and dogs. J. Clin. Invest., 68:39-45, 1981.

Semercioz, A.; Onur, R.; Ogras, S. \& Orhan, I. Effect of melatonin on testicular tissue nitricoxide level and antioxidant enzyme activities in experimentally induced left varicocele. Neuro Endocrinol. Lett., 24(1/2):86-90, 2003.

Sharma, R. K. \& Agarwal, A. Role of reactive oxygen species in male fertility. Urology, 48:835-8, 1996.

Sofikitis, N. \& Miyagawa, I. Experimental models for the study of varicocele: A selected review. Jpn. J. Fertil. Steril., 38:168-77, 1992.

Suziki, N. \& Sofikitis, N., Protective effects of antioxidants on testicular fractions of varicocelized rats. Yonago Acta Medica, 42:87-94, 1999.

\section{Correspondence to:}

Dr L.C. Saalu

Department of Anatomy,

Lagos State University College of Medicine (LASUCOM), Ikeja, Lagos

NIGERIA

Tel: 234-8033200876.

Email: chiasaalu@hotmail.com

Received: 06-01-2008

Accepted:31-03-2008 